\title{
Hard times for the Brazilian
} environment

To the Editor - In the midst of a severe political and ethical crisis, Brazil has suffered several setbacks for environmental conservation. Over the past few months, eagerness to climb out of recession through short-term economic gains combined with the political need to accommodate the powerful Agribusiness Parliamentary Front ( $40 \%$ of the Brazilian Congress) has resulted in a set of bills that will soften environmental licensing ${ }^{1}$, suspend the ratification of indigenous lands ${ }^{2}$, and reduce protection of 600,000 ha of Amazon and Atlantic Forest ${ }^{3}$. Additionally, on 11 July, President Michel Temer passed a law that permits 'land thieves' to legalize their land holdings easily and cheaply ${ }^{4}$.

These changes could not come at a worse time. Data produced in the past two months show that Brazil has experienced an alarming increase in annual deforestation rates. Despite efforts in the past decade to reduce deforestation, high-resolution remote-sensing-derived land-cover classifications ${ }^{5}$ estimate that between 2006 and 2015 Brazil has lost 30 Mha of natural vegetation - aggregation of 13 land cover classes of forests, savannahs, native grasslands and wet ecosystems, covering all six Brazilian biomes. Between 2015 and 2016 deforestation in the Atlantic Forest biodiversity hotspot, already $88 \%$ deforested, reached the highest level in 10 years $(29,100 \mathrm{ha})$, an increase of $60 \%$ over the last year ${ }^{6}$, while in the Amazon it increased 29\% $(789,800 \mathrm{ha})$, the highest in the past eight years ${ }^{7}$. This picture is even worse within the other Brazilian biodiversity hotspot, the Cerrado tropical savannah, which has already lost 88 Mha (46\%) of its native vegetation. On 25 July, the government quietly announced that the Cerrado lost 948,300 ha of native vegetation in 2015 , which was 52\% higher than the Amazon deforestation for the same year ${ }^{8}$.
If deforestation maintains the same rate ( $1 \%$ per year), the Cerrado could lose 1,140 plant species in the next 30 years, a number eight times more species than the number known to have gone extinct worldwide since $1500^{9}$. These alarming deforestation rates across Brazilian biomes have generated consequences that go beyond biodiversity loss and reduction in the provision of ecosystem services, such as carbon storage. On 22 June, the Norwegian Government, the major financier of the Amazon Fund, which is the main funder of actions to prevent, monitor, and combat deforestation in the Amazon, officially informed Brazil that they will halve investment in 2017 or even suspend financial assistance if the new upward trend of deforestation is confirmed in the coming months ${ }^{10}$.

Now that the US has announced it will withdraw from the Paris Climate Agreement, Brazil is expected to play a leading role in environmental negotiations, together with China, South Africa and India. However, while Brazil is starting to build policies to implement its climate commitments, such as recovering $12 \mathrm{Mha}$ of native vegetation ${ }^{11}$, these recent environmental setbacks go against global environmental policies Brazil ratified and puts its chances of combatting deforestation at risk. Brazil will only overcome these hard times when environmental conservation becomes a public policy priority again.

\footnotetext{
Methods

We used the recently launched Mapbiomas ${ }^{5}$, the first monitoring system that covers all Brazilian territory, to estimate native vegetation loss in Brazil between 2006 and 2015. To do so, natural vegetation maps covering $100 \%$ of all six Brazilian biomes in 2005 and 2016 were overlapped. Habitat loss was considered as all natural vegetation existing in 2005 but not in 2016, whereas habitat gain was considered as native vegetation existing in 2016 but not in 2005 . Deforestation was computed as the habitat loss minus habitat gain, providing the net land cover change. We considered as native vegetation 13 land cover classes of forests,
}

savannahs, native grasslands and wet ecosystems: (i) general forest, (ii) natural forest, (iii) dense forest, (iv) open forest, (v) mangrove, (vi) flooded forest, (vii) degraded forest, (viii) secondary forest, (ix) non-forest vegetation, ( $\mathrm{x}$ ) wetlands natural vegetation, (xi) natural grasslands and shrubs, (xii) other natural cover, and (xiii) sand (beach) and dunes.

Renato Crouzeilles ${ }^{1,2,3 *}$, Rafael Feltran-Barbieri ${ }^{4}$, Mariana S. Ferreira ${ }^{5}$ and

Bernardo B. N. Strassburg 1,2,3

${ }^{1}$ International Institute for Sustainability, 22460-320 Rio de Janeiro, Brazil. ${ }^{2}$ Rio Conservation and Sustainability Science Centre, Department of Geography and the Environment, Pontificia Universidade Católica, 22453-900 Rio de Janeiro, Brazil. ${ }^{3}$ Department of Ecology, Universidade Federal do Rio de Janeiro, 68020 Rio de Janeiro, Brazil. ${ }^{4}$ World Resources Institute, 05422-030 São Paulo, Brazil. ${ }^{5}$ Universidade Veiga de Almeida, 20271-901 Rio de Janeiro, Brazil.

*e-mail: renatocrouzeilles@gmail.com

Published: 9 August 2017

DOI: 10.1038/s41559-017-0303-7

References

1. Fearnside. P. M. Science 353, 746 (2016).

2. Portaria $N^{o} 68$ de 14 de Janeiro de 2017 (2017); http://gonature. com/2u4gJFm

3. Medida Provisória No 756 de 19 de Dezembro de 2016 (2016); http://go.nature.com/2vhtste

4. Lei $N^{o} 13.465$, de 11 de Julho de 2017 (2017); http://go.nature. $\mathrm{com} / 2 \mathrm{f} 7 \mathrm{CbYj}$

5. Collection 2 of annual series of land cover and land use in Brazil, 2000-2016. Mapbiomas Project http://go.nature. com/2tJqSIj (2017).

6. Desmatamento da Mata Atlântica cresce quase $60 \%$ em um ano. SOS Mata Atlântica (2017); http://go.nature.com/2uIXy64

7. Taxas anuais do desmatamento: 1988 até 2016. Instituto Nacional de Pesquisas Espaciais (2016); http://go.nature. com/2tJOuwq

8. Análises da antropização. Ministério do Meio Ambiente http://go.nature.com/2tPGaiL (2017).

9. Strassburg, B. B. N. et al. Nat. Ecol. Evol. 1, 0099 (2017).

10. Norway has threatened to cut funds to Brazil unless deforestation slows. Time http://go.nature.com/2u4Y210 (2017).

11. Decreto Federal $N^{\circ} 8.972$ de 23 de Janeiro de 2017 (2017); http://go.nature.com/2vihsHV

Competing interests

The authors declare no competing financial interests. 